\title{
PERFORMANCE OF A SISAL FIBRE FIXED-BED ANAEROBIC DIGESTER FOR BIOGAS PRODUCTION FROM SISAL PULP WASTE
}

\author{
A Mshandete ${ }^{a}$, L Björnsson ${ }^{b}$, AK Kivaisi ${ }^{a}$, MST Rubindamayugi ${ }^{a}$ and B Mattiasson ${ }^{b}$ \\ ${ }^{\text {a }}$ Department of Molecular Biology and Biotehcnology, University of Dar es Salaam, \\ P.O Box 35179, Dar es Salaam, Tanzania. \\ ${ }^{\mathrm{b}}$ Department of Biotechnology, Centre for Chemistry and Chemical Engineering, University of \\ Lund, P.O Box 124, S-22100, Lund, Sweden.
}

\begin{abstract}
A single stage anaerobic digester employing a sisal fibre waste fixed bed was studied for biogas production from sisal pulp waste. The fibre was colonized by microorganisms involved in biogas production. The sisal pulp waste to be digested was fed from the top and was sprinkled intermittently with recirculating leachate from the material. Organic loading rates of 0.1-10 kg volatile solids (VS) $\mathrm{m}^{-3} \mathrm{~d}^{-1}$ could be applied and methane yields in the range of 0.13-0.48 $\mathrm{m}^{3} \mathrm{CH}_{4}$ $\mathrm{kg}^{-1} V S$ added were obtained. The average methane content in the biogas produced from sisal pulp waste was $55 \%$, and the biogas production rate was $0.15-0.54 \mathrm{~m}^{3} \mathrm{~m}^{-3} \mathrm{~d}^{1}$. The methane yield obtained and the highest organic loading rate that could be sustained by this simple, fixed-bed digester are indications of an attractive system in terms of performance and reliability. It is concluded that the sisal fibre waste fixed bed is a promising carrier for microbes and can be employed for long-term operation without changing the bed.
\end{abstract}

\section{INTRODUCTION}

The sisal industry traditionally utilises only $5 \%$ of the total weight of the leaf in sisal fibre production, and the remaining $95 \%$ is being regarded as waste. Fifty-two sisal factories in Tanzania produce about 444,000 tons of waste pulp and 148,000 tons of waste fibre annually, which is often dumped on land or near rivers where it is degraded by microorganisms under uncontrolled conditions. This leads to land, water and air pollution. Sisal waste, however, constitutes a major potential source of clean energy if digested anaerobically under controlled conditions to generate methane. Assuming a standard yield of biogas from biomass wastes of $0.3 \mathrm{~m}^{3}$ biogas $\mathrm{kg}^{-1}$ volatile solids (VS), $16 \times 10^{6} \mathrm{~m}^{3}$ biogas could be obtained from sisal pulp waste with a total solids (TS) content of $14.3 \%(82.3 \%$ of this being VS) and $37 \times 10^{6} \mathrm{~m}^{3}$ biogas from sisal fibre waste (TS $91.6 \%$ of which $92 \%$ is VS). The amount of biogas produced (assuming $50 \% \mathrm{CH}_{4}$ content and complete conversion without losses) would be equivalent to 77 GWh and 183 GWh of electricity from sisal pulp and sisal fibre waste, respectively. To produce one ton of sisal fibre 200-300 $\mathrm{kWh}$ are required (Lock 1969). Thus, for the production of 24,000 tons of commercial sisal fibre in the year 2001, 7.2 GWh of electricity were used (Ronarco 2001). The possibility of using sisal waste for the production of methane could be a costeffective option at sisal factory level, while at the same time reducing environmental pollution.

Anaerobic digestion involves the biological degradation of almost all organic material into biogas. The biogas produced contains methane with contents typically around $60 \%$, which can replace conventional fuels (Chynoweth 2001). It is however, a complex process realised through the combined action of consortia of anaerobic microorganisms (Pavlostathis \& Giraldo-Gomez 1991). The digestion of solid biowaste involves a delicate balance between the rate of hydrolysis and the rate of methanogenesis, as the methanogens are far more sensitive to the accumulation of volatile fatty acids (VFAs) and the corresponding $\mathrm{pH}$ drop, than acidogenic and fermentative bacteria. If the 
rate of hydrolysis is higher than the methanogenic rate, the accumulation of VFAs and hydrogen may lead to irreversible acidification of the digester. Such an effect can lead to cessation of methane production and ultimately process failure (Pavlostathis and Giraldo-Gomez 1991). To alleviate this problem, the application of two-stage systems has been suggested for the digestion of easily hydrolysed organic material in which liquefaction and acidification take place in the first bioreactor and methanogenesis in the second bioreactor. Also two-stage system is beneficial for lignocellulosic material since there will be pretreatment in the acidogenic stage which improves the solubilisation of the organic compounds (Ghosh 1991).

Two-stage bioreactor systems are efficient, but expensive due to high investment and operational cost. They also suffer from problems of clogging or channel formation in the percolated bioreactor (Lettinga and Hulshoff 1991). In the case of lignocellulosic material normally hydrolysis is the rate-limiting step. Therefore acidification of the digester normally does not occur and a two-stage system could not be necessary (Weiland 1993).

Single stage fixed film (bed) is an emerging, attractive, cost-effective simple technology for high solid anaerobic digestion implementation, in which acidogenesis and methanogenesis are partially separated within a single vessel. Hydrolysis and acid formation take place preferentially in the fresh biomass/humid waste fraction at the top of the digester, while gas formation occurs to some extent in the fixed bed bacterial support at the bottom of the digester (Chanakya et al. 1999). Digesters are fed directly with the solid waste instead of first processing the waste into a slurry as is done in conventional digesters. Apart from saving processing time and cost, such digesters often enable handling of higher concentrations of VS per unit digester volume than if the same solids were fed as a slurry (Ramasamy \& Abbasi 2000). Increasing the solid content in anaerobic digestion greatly enhances the economy of the technology due to increased methane production per unit volume of the reactor.

In developing countries such as Tanzania, low-cost systems for biogas production have considerable potential for application and acceptance in rural areas and peri-urban regions where the inhabitants may have no other option for sustainable energy production. Organic support materials such as plant biomass can be used for immobilization of the microorganisms leading to increased population of the microbes, thus enhancing the performance of the fixed bed anaerobic digester. At the same time rigid plant biomass can constitute a humidity reservoir, mechanical support and provide structural stability to the bed. In addition, plant biomass is inexpensive and easily available compared to traditional support materials (Guitonas et al. 1994; Chanakya et al. 1997; Chanakya et al. 1998, Sene et al. 2002, Andersson and Björnsson 2002). Being a solid, lignocellulosic material with 88-90 \% TS, sisal fibre waste is relatively resistant to biodegradation. Furthermore, it is coarse and has a rough surface (Lock 1969). The possibility of utilizing it as a biofilm carrier in a fixed bed digester for converting sisal pulp waste to methane is thus worth investigating.

The objective of this study was therefore to investigate the performance of a single-stage anaerobic digester with sisal fibre waste as the fixed bed when digesting sisal pulp waste, in terms of biogas volume, biogas yield and sustainable organic loading rate.

\section{MATERIALS AND METHODS Experimental set-up}

The digester was made of Plexiglass with a total volume of $2 \mathrm{~L}$ and a $0.9 \mathrm{~L}$ reservoir placed at the bottom of the reactor where leachate was collected and recycled, by means of a peristaltic pump to the top of the 
reactor. The biofilm support, which consisted of sisal fibre waste (SFW), was placed at the lower part of the reactor. During operation, sisal pulp waste (SPW) was added in a batch wise manner and accumulated at the top of the digester. Leachate recycled from the reservoir transported soluble organics from the green biomass down to the methanogenic culture in the SFW bed. Biogas produced was collected into a gas-tight bag at the top of the reactor. The digester was operated at an ambient temperature of $\left(24 \pm 2^{\circ} \mathrm{C}\right)$, without heating the whole reactor because ambient temperatures in East Africa where sisal residues are generated are higher and will permit the utilization of the digesters without heating.

\section{Inoculum and start-up procedure}

In order to obtain quick start-up, predigested SFW was used. Digested slurry (inoculum) used was obtained from a pilotscale wheat straw fixed-bed digester, fed with sugar beet tops, operated for 120 days (Agrigas Research Station, Annerberg, Sweden). SFW and SPW were obtained from a sisal processing factory at Ubena Zomozi in Tanzania. The initial packing density was $30 \mathrm{~kg} \mathrm{~m}^{-3}$, (based on a combination of $78 \%$ pre-digested SFW and $22 \%$ of spent wheat straw). The bed materials were thoroughly mixed with 500 $\mathrm{mL}$ of the inoculum and quickly packed in the digester. The volume occupied by the bed was $1 \mathrm{~L}$ with a bed height of $0.15 \mathrm{~m}$. During start-up of the digester, a continuous leachate flow rate of $0.14 \mathrm{~L} \mathrm{day}^{-1}$ was applied. A low leachate flow rate was applied to prevent the possibility of irreversible acidification of methanogenic pockets. The start-up time took 32 days. The criteria used to determine this start-up period were attainment of $\mathrm{pH}$ above 7.2, partial alkalinity (PA) above $3500 \mathrm{mg}$ $\mathrm{CaCO}_{3} \mathrm{~L}^{-1}$, chemical oxygen demand (COD) below $2000 \mathrm{mg} \mathrm{L}^{-1}$ and total volatile fatty acids below $\left(1000 \mathrm{mg} \mathrm{L}^{-1}\right)$ in the recycled leachate. Further criteria were constant methane content around $(60 \%)$ and insignificant biogas production in last two weeks. During this period no SPW was fed to the system. Following completion of the start-up period SPW was fed to the digester at varying organic loading rates (OLRs). The continuous leachate recirculation during the start-up period was changed to intermittent pumping every 6 hours with a flow rate of $1.0 \mathrm{~L} \mathrm{day}^{-1}$ during experimental operation.

\section{Feedstock and organic loading rates}

The SPW had a TS of $14.3 \% ; 82.3 \%$ of which was VS. The SPW was not diluted. Feeding was achieved by removing a rubber stopper from the feeding port admitting the pre-weighed SPW and replacing the rubber stopper immediately. No compaction of the feed was employed.

Table 1: $\quad$ Feed rates adopted with sisal pulp feed stock

\begin{tabular}{ccccc}
\hline Weeks & Fresh weight (g) & $\begin{array}{c}\text { VS added } \\
\text { gVS 2L }^{-1}\end{array}$ & $\begin{array}{c}\text { LC } \\
\mathbf{g V S ~ L ~}^{-1}\end{array}$ & $\begin{array}{c}\text { OLR } \\
\mathbf{k g V S ~ m}^{-3} \mathbf{d}^{\mathbf{1}}\end{array}$ \\
\hline 1 & 17 & 2 & 1 & 0.14 \\
2 & 34 & 4 & 2 & 0.28 \\
3 & 51 & 6 & 3 & 0.42 \\
4 & 68 & 8 & 4 & 0.57 \\
5 & 85 & 10 & 5 & 0.71 \\
6 & 102 & 12 & 6 & 0.85 \\
7 & 119 & 14 & 7 & 1 \\
8 & 136 & 16 & 8 & 1.14 \\
9 & 153 & 18 & 9 & 1.28 \\
10 & 170 & 20 & 10 & 1.42 \\
11 & 187 & 22 & 11 & 1.57 \\
12 & 204 & 24 & 12 & 1.71 \\
\hline
\end{tabular}


Mshandete et al. - Perfomance of a sisal fibre fixed-bed anaerobic digester ...

\begin{tabular}{ccccc}
\hline Table 1: & Cont. & & & \\
\hline 13 & 221 & 26 & 13 & 1.85 \\
14 & 238 & 28 & 14 & 2 \\
15 & 255 & 30 & 15 & 2.14 \\
16 & 306 & 36 & 18 & 2.57 \\
18 & 374 & 44 & 22 & 3.14 \\
19 & 459 & 54 & 27 & 3.85 \\
20 & 1224 & 144 & 72 & 10.4 \\
\hline
\end{tabular}

The digester was fed at weekly intervals and the organic loading rate (OLR) was gradually increased (Table 1). The OLR, expressed as $\mathrm{kg} \mathrm{VS} \mathrm{m} \mathrm{m}^{-1}$, started at low rates ranging from 0.1 to 2.1 from week 1 to week 15 . Feeding was then increased to moderately high OLRs of 2.5-3.8 kg VS m $\mathrm{m}^{-3}$ during weeks 16-19. At week 17 feeding was not done to allow the system to recover after feeding $2.57 \mathrm{~kg} \mathrm{VS} \mathrm{m}^{-3} \mathrm{~d}^{-1}$ during week 16 .

\section{Stability of the system to overload}

High substrate additions were made in week 20 to test the stability of the system to overload. The reactor was fed three times during this week instead of once and each batch load consisted of $408 \mathrm{~g} \mathrm{(2.19} \mathrm{kg} \mathrm{VSm}^{-}$ ${ }^{3}$ ) of sisal pulp waste. The organic loading rate, expressed in $\mathrm{kg} \mathrm{VS} \mathrm{m}^{-3} \mathrm{~d}^{-1}$ was increased from 3.80 to 6.04 (after first batch addition) from 6.04 to 8.23 (after second batch addition), and finally from 8.23 to 10.4 (when third batch load was added). During each addition, the $\mathrm{pH}$, alkalinity, volatile fatty acids (VFAs), biogas compositions were monitored at 4, 8, 20, 24 and 72 hours. Digestion was then allowed to proceed for two weeks, up to week 22 to monitor the system performance.

Continuous operation was limited by the volume of the digester. However, we did not increase the digester volume as this would have lead to an increased cost. Digested SPW was thus removed when the digester was full in order to create space for continued operation. The digested SPW at the top of the digester was removed by opening the digester at the top during weeks 15 and 18 . Before emptying, any liquid in the digester was allowed to drain into the reservoir.

\section{Analytical methods}

The biogas volume was measured with a wet-type precision gas meter (Schlumberger, Karlsruhe, Germany). Biogas composition, partial alkalinity (PA), total alkalinity (TA), $\mathrm{pH}$ and VFAs were measured every 24 hours after feeding SPW using methods previously described by Björnsson et al. (2000). The gas composition was determined by gas chromatography (Varian 3350, Walnut Creek, CA, USA). VFAs were monitored with high performance liquid chromatography (Varian 9000 HPLC, Walnut Creek, CA, USA), using a BioRad column (Biorad 125-0115, Hercules, CA, USA), column for fermentation monitoring. UV absorbance at $208 \mathrm{~nm}$ was used for peak detection. Samples for VFAs analysis were centrifuged at $3000 \mathrm{x} \mathrm{g}$ for $3 \mathrm{~min}$ and the supernatant was acidified with concentrated sulphuric acid. The samples were stored at $-20^{\circ} \mathrm{C}$ until analysis. Before analysis, the samples were thawed and filtered through $0.45 \mu \mathrm{m}$ filters (Minisart, Satorius AG, Göttingen, Germany). The $\mathrm{pH}$ and alkalinity were monitored using a TIM titration manager with an ABU 901 Autoburette (Radiometer Copenhagen, Denmark). Samples were centrifuged at $3000 \mathrm{x}$ g for 3 $\mathrm{min}$, and $6 \mathrm{ml}$ of the supernatants were used. TS and VS were analysed according to standard methods (APHA 1985).

\section{RESULTS AND DISCUSSION}

\section{Structural stability of the bed and} leachate recirculation

The original volume of the SFW bed decreased by $40 \%$ after 6 months of operation. Despite the fact that the sisal fibre 
waste bed was partially degraded, it still had sufficient structural stability at the end of the experimental run of 6 months. In a fullscale system, exchanging or replenishing bed material on this time scale is feasible. During the 6 months of operation, no clogging, drainage, or foaming problems were encountered, even with high batch loading. It is possible that intermittent pumping allowed for drainage hence preventing free liquid in the digester from causing the biomass to float. in fixed-bed reactors for biogas production from crop residues. However, the extent of shrinkage depends on the organic support used, the packing density and scale, as well as the age of the bed. For example, in their laboratory-scale study of a straw fixed-bed reactor of $105 \mathrm{~kg} \mathrm{~m}^{-3}$ packing density, Svensson et al. (2002) observed $80 \%$ decrease in the original volume when the straw was 274 days old. The original volume was reduced by a further $6 \%$ from day 274 to day 326 .

Bed shrinkage has been reported by others using organic materials for bacterial support

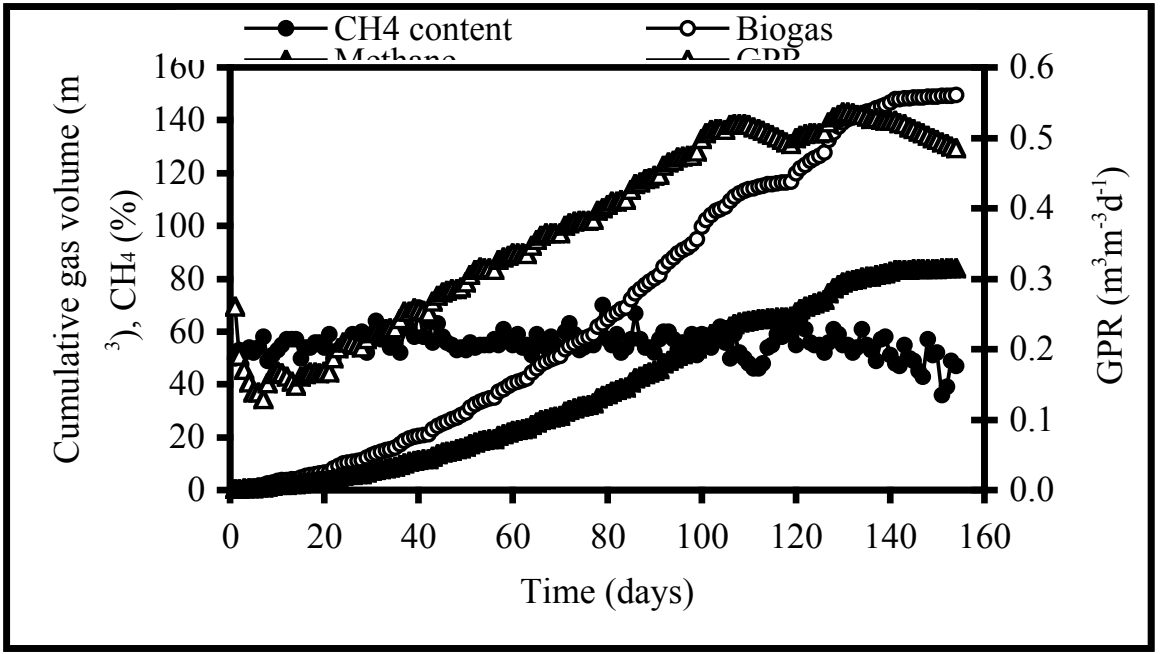

Figure 1: The cumulative gas volume, gas production rate and biogas composition during anaerobic digestion of sisal pulp waste in the sisal fibres waste fixed-bed digester

\begin{abstract}
Biogas composition, production and methane yield

Although some air was introduced during the addition of SPW, the overall process was not affected. The air introduced may have been consumed by facultative anaerobic fermenting bacteria during the hydrolysis and acidification of SPW loaded in the top of the digester. The methanogens colonized the lower part of the decomposed material of the bed and the oxygen introduced at the top of the bed could not easily reach these lower
\end{abstract}

layers. The results in Figure 1 show cumulative biogas volume and gas production rate (GPR). The daily observed GPR expressed as $\mathrm{m}^{3} \mathrm{~m}^{-3} \mathrm{~d}^{-1}$ ranged between 0.15 and 0.54 , generally increased with time when fresh biomass was added in the digester. The GPR achieved in this study was comparable to that observed in the digestion of leaf biomass in plug flow digesters $\left(0.5 \mathrm{~m} \mathrm{~m}^{3} \mathrm{~m}^{-3} \mathrm{~d}^{-1}\right)$ (Chanakya et al. 1997). Chanakya et al. (1993) previously reported a GPR range of $0.5-0.6 \mathrm{~m}^{3} \mathrm{~m}^{-3} \mathrm{~d}^{-1}$ 
during solid-phase fermentation of untreated leaf biomass. The average methane content of $55 \pm 5 \%$ obtained in this study compares well with that $(50 \%)$ obtained from anaerobic digestion of fresh beet tops and ensiled ley crops (6:1 wet mass ratio) in a single-stage wheat straw fixed-bed digester (Svensson et al. 2002). Previously, on digesting leaf biomass and urban market waste in a solid-phase biogas fermenter, Chanakya et al. (1999) also obtained 50$60 \%$ methane content in the biogas produced. These observations show that the GPR and methane content obtained in this study are typical of a single-stage fixed-bed digester treating plant biomass.

The rate of charging the digester is important; continuous addition of small amounts of the feedstock is best and the most practical compromise is daily addition of uniform amounts. As can be seen in Figure 2, low $\left(0.1-2.1 \mathrm{~kg} \mathrm{VS} \mathrm{m}^{-3} \mathrm{~d}^{-1}\right)$ to moderately high (2.5-3.8 $\left.\mathrm{kg} V \mathrm{VS} \mathrm{m} \mathrm{m}^{-3} \mathrm{~d}^{-1}\right)$ organic loading rates were possible and gave methane yields in the range of $0.13-0.48 \mathrm{~m}^{3}$ $\mathrm{CH}_{4} \mathrm{~kg} \mathrm{VS}^{-1}$ added which decreased with an increasing OLR. In earlier work, Chanakya et al. (1999) reported methane yields in the range of $0.11-0.28 \mathrm{~m}^{3} \mathrm{CH}_{4} \mathrm{~kg} \mathrm{VS}^{-1}{ }^{*}$ for fermentation of plant biomass digested in a solid-phase biogas fermenter. (*Values calculated from the data reported). Recently, Svensson et al. (2002) reported methane yields ranging between 0.30 and $0.40 \mathrm{~m}^{3}$ $\mathrm{CH}_{4} \mathrm{~kg} \mathrm{VS}^{-1}$ from crop residues digested in a single-stage wheat straw bed digester. The methane yield data obtained in this work fall within values of literature for digestion of plant biomass in solid-phase bed digesters.

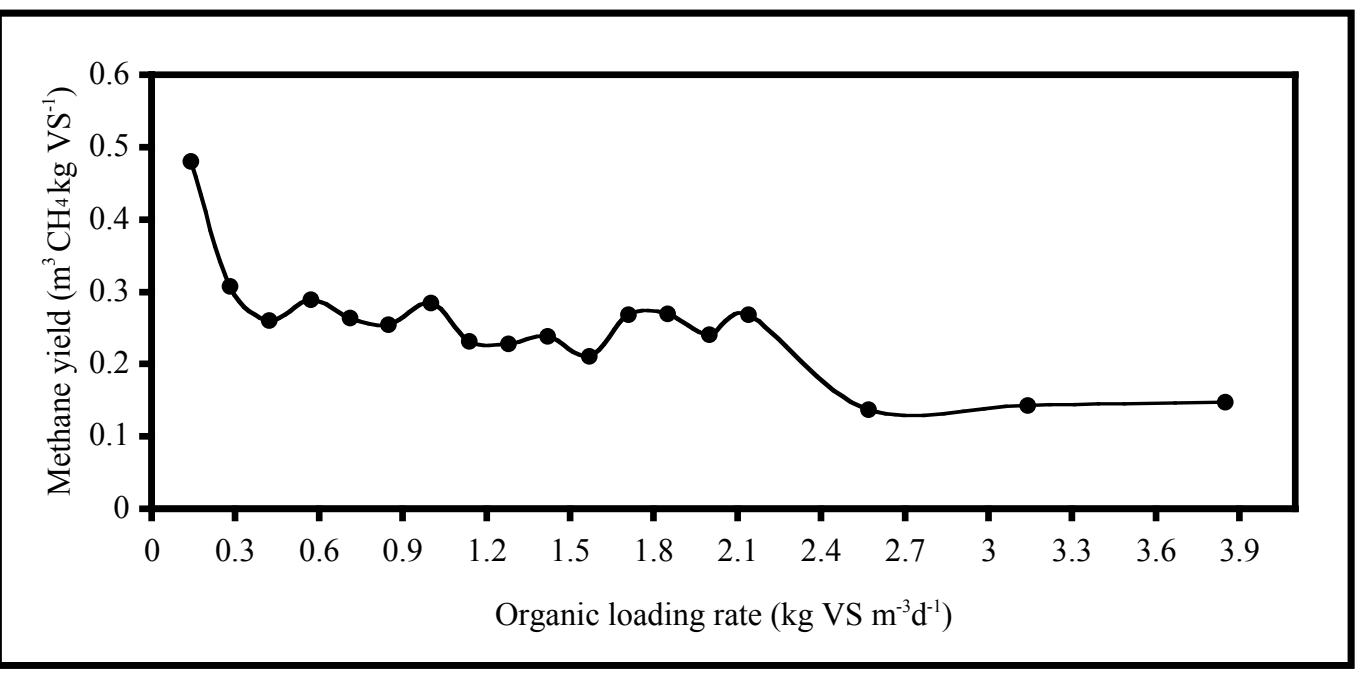

Figure 2: $\quad$ Methane yield for sisal pulp waste at low $\left(0.1-2.1 \mathrm{kgVSm}^{-3} \mathrm{~d}^{-1}\right)$ to moderate high (2.51-3.8 $\left.\mathrm{kgVSm}^{-3} \mathrm{~d}^{-1}\right)$ organic loading rates in the sisal fibres fixed bed digester

Stability of the system against overload

As seen in Figure $3 a, b$ and $c$, the addition of three batch loads, each consisting of 2.19 $\mathrm{kg} \mathrm{VS} \mathrm{m}^{-3}$ to a normal load of $3.8 \mathrm{~kg} \mathrm{VS} \mathrm{m}^{-}$ ${ }^{3} \mathrm{~d}^{-1}$ in a week corresponding to an increase in OLR of $6-10 \mathrm{~kg} \mathrm{VS} \mathrm{m}^{-3} \mathrm{~d}^{-1}$, did not cause serious imbalance in the digester. Even with digester liquid VFA concentrations between 1200 and $2600 \mathrm{mg} \mathrm{L}^{-1}$, the process $\mathrm{pH}$ and PA were stable at around 7.3 and 3000-3900 mg CaCO $\mathrm{L}^{-1}$, respectively. This finding is important, and shows that the bacterial sisal fibre waste support system can withstand the fluctuations in VFAs when high batch loads 
are added to the system. The ability of the digester to handle higher OLRs of up to 10 $\mathrm{kg}$ VS $\mathrm{m}^{-3} \mathrm{~d}^{-1}$ without serious process stress indicates reliable performance of the singlestage system tested. The highest OLR sustained by the present digester is comparable to the $9-10 \mathrm{~kg}$ VS $\mathrm{m}^{-3} \mathrm{~d}^{-1}$ suggested by Chanakya et al. (1997) as being optimal and practically attractive for solid-phase biogas fermenter digesting leafy biomass feedstock.

\section{The overall characteristics of the digester} liquid

The results in Figure 4 show that the $\mathrm{pH}$ was above 7 , and the PA ranged between 3000 and $4000 \mathrm{mg} \mathrm{CaCO}_{3} \mathrm{~L}^{-1}$. However, there was an initial decrease in $\mathrm{pH}$ and $\mathrm{PA}$ at 4,8 and 20 hours after feeding moderately high OLRs of $2.5-3.8 \mathrm{~kg} \mathrm{VS} \mathrm{m}^{-3} \mathrm{~d}^{-1}$ (results not shown), which subsequently increased to higher $\mathrm{pH}$ and PA levels 24 hours after each batch was added. The tendency towards initial fall in $\mathrm{pH}$ and PA upon feeding may have been caused by the degradation of SPW, which produced more organic acids. The increase in PA with time can probably be attributed to the increase in $\mathrm{NH}_{4}^{+}$ resulting from the feed mineralization. Similar observations have been reported by Svensson et al. (2002), when studying laboratory-scale fixed-bed anaerobic digester.

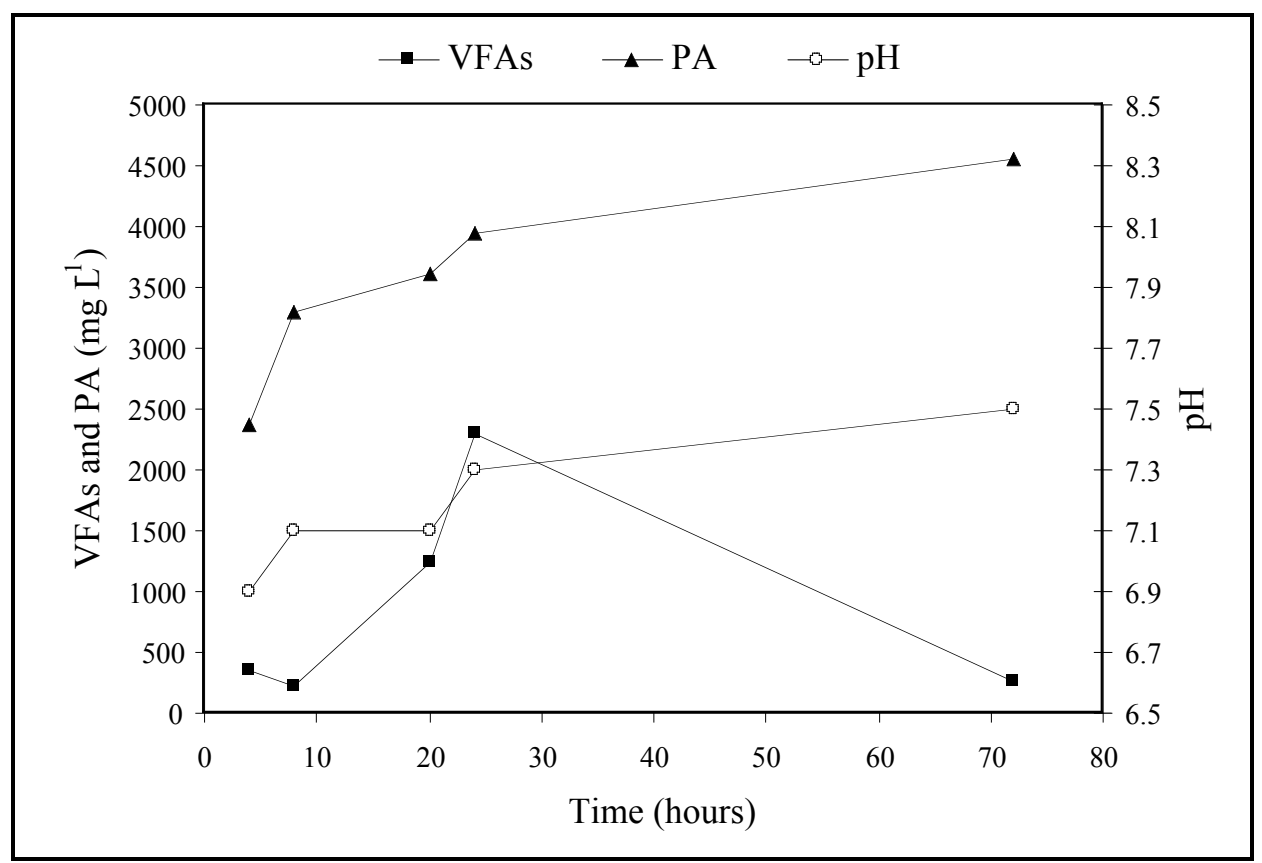

Figure 3a: Composition of the digester liquid after of addition of $2.19 \mathrm{kgVSm}^{-3}$ during stability testing. First pulse $6.04 \mathrm{kgVSm}^{-3} \mathrm{~d}^{-1}$ 


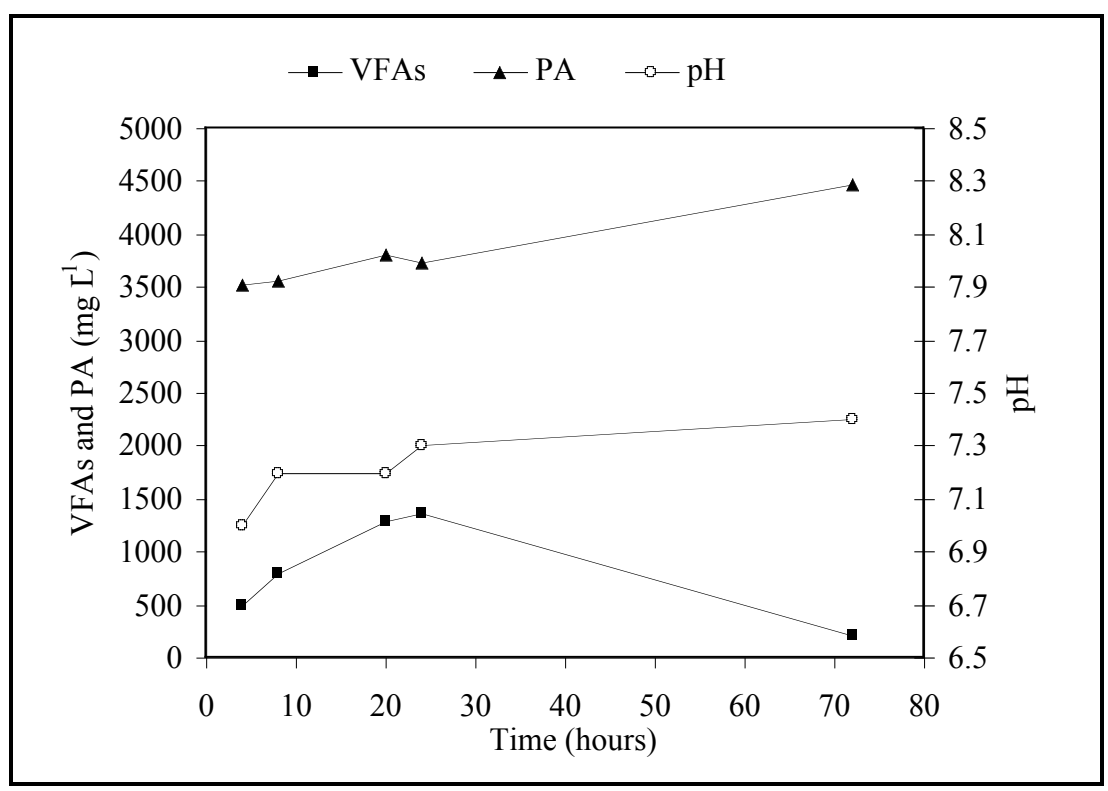

Figure 3b: Composition of the digester liquid after of addition of $2.19 \mathrm{kgVSm}^{-3}$ during stability testing. Second pulse $8.23 \mathrm{kgVSm}^{-3} \mathrm{~d}^{-1}$

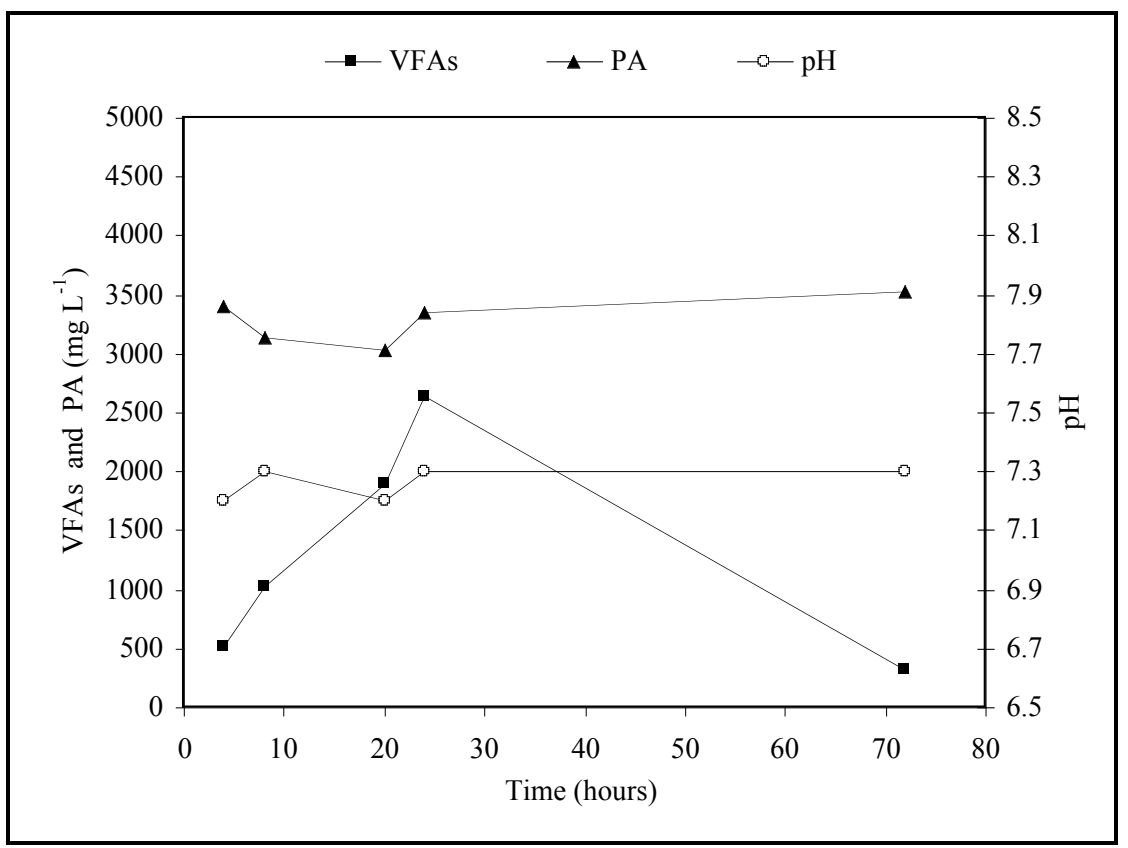

Figure 3c: $\quad$ Composition of the digester liquid after of addition of $2.19 \mathrm{kgVSm}^{-3}$ during stability testing. Third pulse $10.4 \mathrm{kgVSm}^{-3} \mathrm{~d}^{-1}$ 


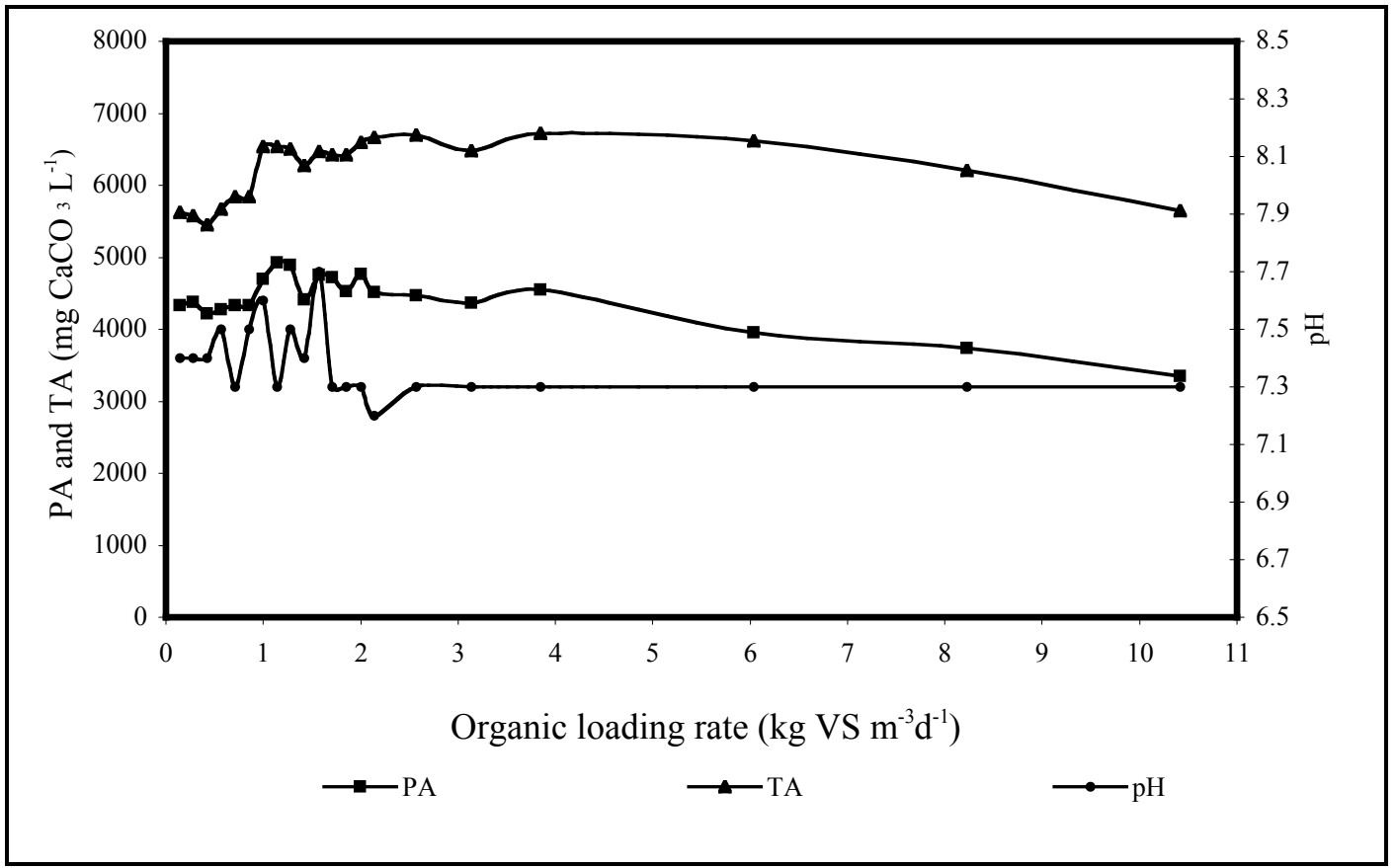

Figure 4: The $\mathrm{pH}$ and partial and total alkalinity profiles of the digester liquid which was determined every 24 hours after feeding the sisal pulp waste in the digester.

The total VFA concentrations at different OLRs, recorded 24 hours after feeding are presented in Figure 5. The total VFAs varied between 3000 and $3900 \mathrm{mg} \mathrm{L}^{-1}$ at different OLRs investigated. However, the total VFAs recorded 4, 8 and 20 hours after feeding moderately high OLRs $2.5-3.8 \mathrm{~kg}$ VS m $\mathrm{m}^{-3}$ reached $5000 \mathrm{mg} \mathrm{L}^{-1}$ (results not shown). The levels of VFAs accumulation at different OLRs demonstrated an irregular pattern. This shows that it is not feasible to define an absolute VFA level indicating the state of the process under the operating conditions used in this study. However, it is interesting to note that even at VFA concentrations as high as $5,000 \mathrm{mg} \mathrm{L}^{-1}$ in the digester liquid no detrimental effect on the process was observed. These results show that the system was well self-buffered, which enabled the established methanogenic culture to degrade the volatile fatty acids formed in the process. Chanakya et al. (1993) observed no suppression of gas production in the biomass bed when the VFA levels in the digester liquid was below $6000 \mathrm{mg} \mathrm{L}^{-1}$, when digesting untreated leaf biomass by solid-phase fermentation. This observation is comparable to that of the present study. Furthermore, the range of the propionic acid: acetic acid ratio of $0.20-1.30$ obtained in this study is below the value of 1.4 suggested for unstable process by Hill (1982). Sisal fibre waste has been found to be a promising carrier for the microbes in the SPW digestion since the vulnerable microorganisms under these conditions seem to be able to sustain much larger changes in VFAs concentrations. 


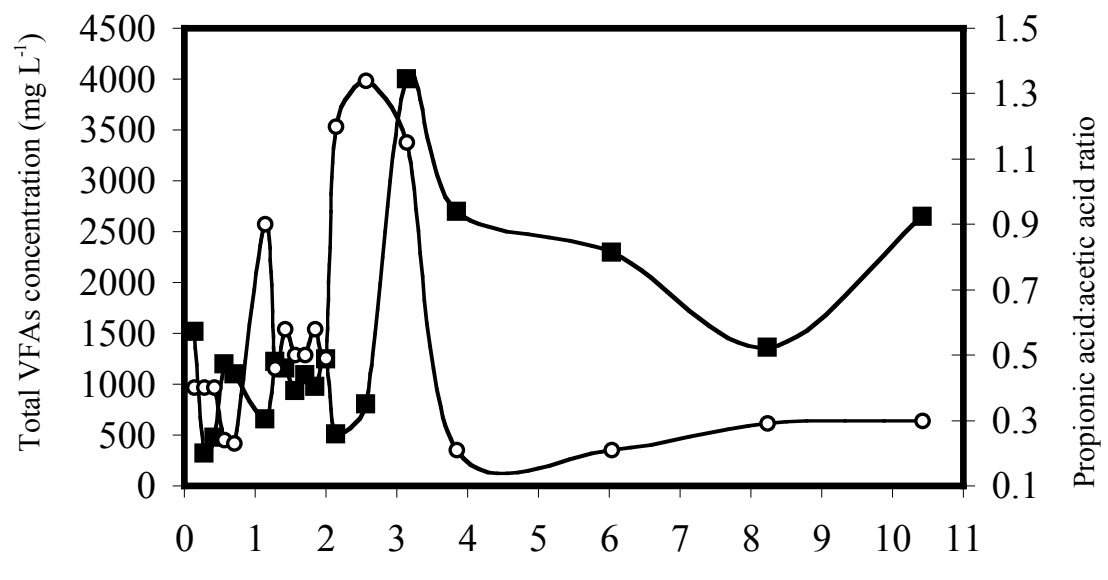

Organic loading rate $\left(\mathrm{kg} \mathrm{VS} \mathrm{m}^{-3} \mathrm{~d}^{-1}\right)$

$\rightarrow$ Total VFAs $\quad \longrightarrow$ Propionic:acetic acid

Figure 5: Total concentration of VFA accumulation profiles after 24 hours feeding the green biomass and the propionic acid/acetic acid ratio at different organic loading rates in a waste sisal fibres fixed bed reactor digesting sisal pulp waste.

\section{CONCLUSIONS}

The results of this study show that the digestion process can be run at OLR of 10 $\mathrm{kg}$ VS m $\mathrm{d}^{-1}$ without causing instability, indicating that the process can be run costefficiently on laboratory-scale. However, it remains to be seen whether this is possible on pilot and larger scale. Methane yields between 0.14 and $48 \mathrm{~m}^{3} \mathrm{CH}_{4} \mathrm{~kg} \mathrm{VS}^{-1}$ with $50-60 \%$ methane content is promising for energy generation from SPW, which could be used at sisal factory level. One factory in Tanzania with the potential to generate about 8,000 tons of SPW per year $(14.3 \% \mathrm{TS}$, $82.3 \%$ of which is VS) could be capable of generating about 140,000-480,000 $\mathrm{m}^{3} \mathrm{CH}_{4}$ per year. This is equivalent to about 1.4 GWh-4.7 GWh of electricity. This is ten times the energy consumption of the factory when producing 460 tons of commercial sisal fibre. The generation of electricity from biogas is thus highly advantageous compared with releasing SPW untreated.

In conclusion, SFW has shown to be a promising biofilm carrier in fixed-bed anaerobic digester for SPW digestion. Besides being abundant and inexpensive, both sisal fibre and sisal pulp are wastes produced in sisal factories, which makes scale-up of a fixed-bed digester at sisal factory level feasible and cost-effective, with respect to handling and transport.

\section{ACKNOWLEDGEMENTS}

This work was supported by the Swedish International Development Agency (Sida/SAREC) through BIO-EARN (East African Regional Programme and Research Network for Biotechnology, Biosafety and Biotechnology Policy development) programme and the Energy Supply Committee of Southern Sweden (DESS); their financial support is gratefully 
acknowledged.

\section{REFERENCES}

Andersson J and Björnsson L 2002 Evaluation of straw as a biofilm carrier in the methanogenic stage of two-stage anaerobic digestion of crop residues. Bioresource Technology 85: 51-56.

APHA, 1985. Standard Methods for examination of water and wastes. $16^{\text {th }}$ ed., American Public Health Association, Washington DC, USA.

Björnsson L, Murto $\mathrm{M}$ and Mattiasson $\mathrm{B}$ 2000 Evaluation of parameters for monitoring an anaerobic co-digestion. Applied Microbiology and Biotechnology 54: 844-849.

Chanakya HN, Venkatsubramaniyam R and Modak J 1997. Fermentation and methanogenic characteristics of leafy biomass feedstocks in a solid phase biogas fermentor. Bioresource Technology 62: 71-78.

Chanakya HN, Srivastav GP, and Abraham AA 1998 High rate biomethanation using spent biomass as bacterial support. Current Science 74: 1054-1059.

Chanakya, HN, Srikumar KG, Anand V, Modak J and Jagadash KS 1999 Fermentation properties of agro-residues, leaf biomass and urban market garbage in a solid phase biogas fermenter. Biomass and Bioenergy 16: 417-429.

Chanakya HN, Borgaonkar S, Meena G and Jagadash KS 1993 Solid phasefermentation of untreated leaf biomass to biogas. Biomass and Bioenergy 5: 369377.

Chynoweth DP, Owens JM and Legrand R 2001 Renewable methane from anaerobic digestion of biomass. Renewable Energy 22: 1-8.

Ghosh S 1991 Pilot-scale demonstration of two-phase anaerobic digestion of activated sludge. Water Science and Technology 23: 1179-1188.
Hill TA 1982 Comprehensive dynamic model for animal waste methanogenesis. Trans ASAE 25: 1374-1380.

Guitonas A, Paschalidis G and Zouboulis A 1994 Treatment of strong wastewaters by fixed bed anaerobic reactors with organic support. Water Science and Technology 29: 257-263.

Lettinga $\mathrm{G}$ and Hulshoff PLW 1991. UASB process design for various types of wastewaters. Water Science and Technology 24, 87-107.

Lock GW 1969 Sisal thirty years' of sisal research in Tanzania. $2^{\text {nd }}$ ed., Spottiswoode, Ballanttyne and Co LTD, London and Colchester.

Pavlostathis SG and Girado-Gomez E 1991 Kinetic of anaerobic treatment: A Critical Review. Critical Reviews in Environmental Control 21: 411-490.

Ramasamy EV and Abbasi SA 2000. Highsolid anaerobic digestion for the recovery of energy from municipal solid waste (MSW). Environmental Technology 21: 345-349.

Ronarco BV 2001 Sisal the plant. Viewed on 1/8/2002. http://www.sisal.ws/sisal. fibre.html.

Sene L, Converti A, Felipe MGA and Zilli M 2002 Sugar cane as an alternative packing materials for biofiltration of benzene polluted gaseous streams: a preliminary study. Bioresource Technology 83: 153-157.

Svensson ML, Bjornsson L, Batstone D and Mattiasson B 2002 The effect of packing density on the start up and operation of an anaerobic single stage fixed wheat straw bed digester. Anaerobic Digestion of Solid Wastes, Proc.IWA 3rd Inter Symp, Sep 2002. Munich/Garching, Germany, poster 14.

Weiland P 1993 One- and two-step anaerobic digestion of solid agro industrial residues. Water Science and Technology 27: 145-151. 